\title{
Levels of Communication Act: Functional Communicative Features of Social Work Institutional Discourse
}

\author{
Sergey Bredikhin ${ }^{1, *}$, Yuliya Bredikhina $^{2}$, Svetlana Serebriakova ${ }^{1}$, Tatiana Marchenko ${ }^{1}$ \\ ${ }^{1}$ North-Caucasus Federal University, Department of Translation Studies, 355009, 1 Pushkin St., Stavropol, Russia \\ ${ }^{2}$ Committee of Labour and Social Protection of Population of the Administration of Stavropol, 355029, 415 b Lenin St., Stavropol, \\ Russia
}

\begin{abstract}
The article studies basic functional communicative features of social work discourse. Assuming the actualization of triple communication bonds "a social worker - a client - a social service" in social work interaction, the authors study the key levels of communicative actions, which verbalize both institutional and personal elements in this communication domain. The approach provides an opportunity to specify social work discourse as a contaminated phenomenon combining the features of a social-ritual kind within the institutional type of discourse and an existential kind within personality-oriented type of discourse. The linguistic means of actualizing conventional components of this type of discourse are determined.
\end{abstract}

\section{Introduction}

The article studies functional communicative features of social work discourse in written form as a special socialritual kind of institutional communication accompanied by typical conditions of actualization.

Social work discourse has not been in the focus of research. It should be noted that institutional features of this type of communication are preconditioned by the situational context of discourse formation and convey special features due to the third regulating part. It is important to emphasize that in standard two-focus situations with acting counter communicants "social worker - client" there is a third institution, a social service, which conventionalizes the communication process. It makes the communicants subject the remarks to a secondary review [1].

Thus, social work discourse can be defined as a macro-speech act aimed at realization of different intentions of communicants, such as assertive, directive and commissive ones. At the same time, counter communicants convey different social roles representing social institutions and personalities as a counteragent in relation to a social worker as well as the public institution of social work in general. The interaction of participants is predetermined by situational context and status roles of counter communicants. It is the situation of communication that specifies the context. It poses the main and immanent condition of the adequate character of discourse [2].

In the present study we set out to specify, analyze and classify functional communicative features of social work institutional discourse, which is predetermined by a specific communication situation within the framework of hierarchical system of communicative action.
The object of the study concerns language and text means employed to actualize certain levels of communicative action in social work discourse. The extralinguistic context and the vectors of discourse development precondition its institutional and personal characteristics. Social work discourse has recently become the focus of attention in modern philology. It appears to be of special interest essentially due to studies related to social status explication in speech. The tendency is also attributed to the growing role of social welfare institutions and the necessity to provide highquality social programs both in Russia and abroad, as well as ongoing interaction of international and national organizations aimed at the development of such programs. With regard to other genres of institutional discourse, socially oriented communication is basically characterized by specific pragmatic focus, discoursegenre peculiarities and a peculiar language register. The combination of the above-mentioned parameters enables one to assume that social work discourse is a prototypic model of institutional discourse.

A file incorporating stereotypical contexts, which happened to be a part of working experience of the staff members of Labour and Social Welfare Committee in Stavropol, as well as written appeals from citizens (20162017), served the material of the study.

\section{Methodology}

Dominant guidelines of the analysis and the aims of the study preconditioned the use of a set of linguistic methods: speech act analysis, discourse-analysis, interpretative method, method of phenomenological reduction, methods of philological hermeneutics.

* Corresponding author: bredichinsergey@ yandex.ru 
The methodological base of the study served the works on different types of discourse. For instance, V.I. Karasik, giving an account of different types of institutional discourses, does not specify complex, contaminated types [3], which are of special interest in terms of defining the parameters for classification more accurately and identifying different discourse genres in a more precise way. We also referred to the works on analysis of a functional aspect of status-role communication [4] as well as works highlighting the peculiarities of business communication modelling within the framework of expressing a social status and the means to manage communication [5]. The methodology of the study was significantly influenced by T. van Dijk's work on actualization of mental models of expressing the social status [6].

Cognitive and discourse studies claim that discourse is amphibolic by nature. Namely, the above-mentioned methods allow specifying and analyzing the most relevant communication features in social work discourse as well as concurrent, formal and connotative-meaning variable indicators (e.g. the degree of variability of text and language means or illocutionary aims of utterance formation).

\section{Analysis}

In social work discourse, the text is viewed as 1) a part of written or oral speech, which actualizes the prototypic situations of appeal, complaint, request or notification by language means, and as 2) content unity that realizes a particular communication intention of one of the communication parties in a "social worker - client social service" triad. The structure of social work is actualized in a regulated complex system of public service, which is verbalized according to communication principles of official communication, i.e. follows the requirements of consistency and accuracy of verbalization, reasoning as a means to prove the compliance or non-compliance with federal laws, internal regulations, etc. Following Th. Burghard, the social work discourse is a certain dialogical paradigmal hierarchy; the formant analysis within it is carried out in accordance with a cyclotomic model [7]. One can specify some constitutive features distinguishing this intermediate type from other institutional genres in realization of different communication actions, which are verbalized by heterogeneous and amphibolic speech acts. The latter fall into particular structural types expressed by speech elements of different levels.

Within communicative actions in social work discourse at the initial stage of inchoative-formalinstitutional communication, it is essential to specify constitutive features of speech acts "appeal", "complaint" and other per se:

Awareness of the "client"-producer of the initial appeal to the social service as regards to certain rights on the part of public social services, public authorities, etc.; or the awareness of one's "great distress".
Realization of illocutionary aim to inform relevant services or authorities concerning the awareness, clarification of the state of things on the relevant topic.

Intentional character of emotion-provoking speech act aimed to actualize a particular perlocutionary effect (to arouse sympathy, to provoke personal interest on the part of a social worker in order to comply with a request, etc.)

Intentional conflict-provoking character of these speech actions as a concurrent purpose;

Phatics realization - drawing attention of social workers within faulty adoption of a special status model (sometimes with the reference to intimidation and confrontation strategies);

Intensification of illocutionary aims by means of numerous references to certain facts concerning the relevant situation, invariable emotive character of utterances.

Distinguishing social work discourse from other types of institutional communication, we, following V.I. Karasik, assume the possibility of analysis of the discourse under consideration in line with other types of institutional discourses - scientific, political, legal, medical-pedagogical and other [3].

The peculiarities of institutional parameters in socialrelevant communication concern the combination of pragmatic and communicative aspects of discursive practices as the main condition to express conventional aspects. These combinative forms are present at four complementary levels of communicative action. It should be noted that the indication of status roles in such borderline type of discourse can be actualized both at the level of direct ("client - social worker") and indirect contacts ("client - social service") [8].

At the first level of manipulation, the subject of communication (the client) can view a counter communicant (a social worker or the social service in general) as a means to reach or a hindrance to perlocutionary effect (to realize what is wished in objective reality). At this stage, the "partnership" communication model is realized. It consists in informing of the essence of the problem and the request. According to this model, the communication is presented by the source (the addressant) and the recipient (the addressee) of the information. The status of a communicative action is supposed to be preconditioned by its key factors and the results, e.g.: U menya uzhe est' nekotoraya informatsiya po dannomu voprosu, naprimer, o poryadke vyplat po invalidnosti, no ne sistematizirovannaya i ne za ves' period nachisleniya v 2015 godu. Po voprosu dopolnitel'nykh platezhey, ya imeyu v vidu, naprimer, edinovremennye denezhnye vyplaty pensioneram ili kompensatsii raskhodov na ZhKKh i pr. (card-file). - I already have some information on the topic, for example on the disability allowance. However, it is not consistent and does not cover the whole period of 2015. On extra payments, I mean for example the one-off payment to pensioners or housing services and utilities allowance and other (translated by the authors).

In the given context, the addressant (the client) employs a whole array of manipulation strategies to actualize its illocutionary goals. In most cases it happens unconsciously and not without a reason this subtype of 
intermediate discourse is characterized by K. Stenson as "the client's discourse as involving a primitive and ad hoc stringing together of representations of concrete experiences, with little attempt at manipulating abstractions" [9]. Following Karasik, the given level is aimed at expression of personal-status meaning. It is expressed most obviously in the reference to personal and possessive pronouns of the first person, which is evident manifestation of a deictic feature related to the personalstatus complex [8].

Moving on to the second level of a "reflexive game", each counter communicant relies on his / her background knowledge and takes into account the opportunities of counter arguments on the part of the other subject of communication. At the same time, the communicant does not admit the dominance of other participants of communication and seeks to reach his / her own goal and prevent the goals of counteragents, i.e. a "bilateral asymmetric" model with a primary persuasion dominant is applied.

Communication connections are presented by the source (a client), the recipient (a social worker) and initial feedback (the feedback from official bodies concerning the given object of communication). Communication action of the subject is of complex nature, which is determined by the context of address (complaint, appeal, demand, etc.). This level of communicative action features almost limit concentration of status evaluation meanings, namely the explication of a "Strong Positivist" position as represented by a social worker, and a "Weak Positivist" as represented by the client of the social service; sometimes the client realizes the position of a "Weak Negativist" [8].

E.g.: Ya znayu o sushchestvovanii ukaza prezidenta Rossiyskoy federatsii o naznachenii dopolnitel'nykh vyplat po kompensatsii raskhodov na kapital'nyy remont, ob etom soobshchali po televideniyu, pochemu rabotniki komiteta ne proizveli pereraschet (card-file). - Following the TV-news, I'm aware of the Decree of the President of Russia which stands for providing extra funds to set off the costs of major overhaul. Therefore, I wonder why the committee stuff have not made any reassessment (translated by the authors).

The third communication level in social work discourse is the "consolidation". Counter communicants accept the arguments expressed by other participants. The action is followed by coordination of a unified position as regards the problem under consideration. The level entails the development of obligatory norms and coordination conditions for all participants of communication. At the same time, the "bilateral asymmetric" model under ideal conditions is replaced by the "bilateral symmetric" one, which reflects mutual pursuit of solution.

E.g.: V ramkakh Vashego obrashcheniya byl proizveden pereraschet, kotoryy nosit otritsatel'nyy kharakter, v svyazi s chem vozmozhno prodolzhenie vyplat $\mathrm{V}$ sokrashchennom ob"eme $\mathrm{v}$ techenie sleduyushchego kvartala tekushchego goda (card-file). In accordance with your appeal there has been made reassessment that is of negative nature, therefore the continuation of allowances in reduced amount is possible within the next quarter of the current year (translated by the authors).

At this stage, the contradiction between institutional and personal elements is virtually solved by the intentional aim to come to common ground and use specific strategies: "this strategy operates within the medium of citizen exchange discourse. This technique of alignment is a dimension of the wider process of alignment, whereby governmental strategies try to link individual aspirations with collective goals" [9].

It is worth mentioning, that the level features the principle of politeness intentionally aimed at the addressee. It simultaneously fulfills connotative function and the communicative behavior of both counter communicants reveals "modesty" (the true or the simulated ones), which demonstrates the position of the addressant, acting as the subject, which does not deserve any external demonstration of appreciation within the framework of a particular act of communication. "Modesty" as a criterion indicator of consolidation refers to the addressant and conveys the emotional function [10].

The fourth level of communication actions in social work discourse is not actualized in its written form, whereas in oral communication "client - social worker" there is a possibility of transition to this "intentionalmoral" stage. It is the highest level of subject-subject relations, and it can result in the shift from social-ritual institutional type of discourse to the existential personoriented type. Thus, within interpretation of all possible types of social-oriented communication the constitutive features of social work discourse are represented by the trifocal principle of communication construction - two direct and indiscrete subjects (the client and the social worker) and one common shared discrete subject (the social service); a prospective but rarely used opportunity to change the type and the kind of discourse, which presupposes the change of "cognitive code from inchoativ-formal-institutional to durative-personalexistential, and in some cases back to final-formalinstitutional" [1]. At this level counter communicants represent inner conviction in a reasonable and correct way of collateral actions aimed at solving extracommunication tasks and define this conviction as the result of voluntary coordination and acceptance of a certain order of actions. The level follows the "bilateral symmetric" model with formal language markers of reaching mutual understanding. The communication connections revealed at the stage are Subject 1 (the client) - Subject 2 (the social worker) - feedback. As regards the awareness of the concept-value system of counter communicants and sharing value implications of each other, the communication is of complex activity character, and it, in particular, determines the degree and the character of mutual understanding - "these emphasized the need to recognize and foster the emotional needs of the client" [9]. Under the circumstances when social roles are supposed to be observed (in discourse under consideration), the degree of mutual understanding and adequate communication action depends on how, to what extent Subject 2 takes part in the extralinguistic situation relevant for Subject 1, and the willingness of counter communicants to make mutual concessions and tune all 
communication actions in line with formal regulators, stipulated by laws, internal regulations, etc.

E.g.: Staff member of Labour and Social Policy Committee: Teper' yasno, chto pri soblyudenii dannogo grafika vyplat i uderzhaniy budet soblyudena zakonnost' i Vy kak ikh poluchatel' ne budete ushchemleny v svoikh pravakh.

Client: Da, pravda, teper' Vy menya proinformirovali i ya soglashus' $\mathrm{s}$ takim pereschetom, tem bolee chto vyplaty sokhranyayutsya prakticheski v polnom ob'eme (card-file). -

Staff member of Labour and Social Policy Committee: Now it is clear that following the given schedule of payments and deductions, the law will be observed and the rights of the beneficiary will not be violated.

Client: Yea, exactly, now you have informed me and I can accept the reassessment, given the fact that the allowance is retained in almost full amount (translated by the authors).

It should be noted that explicit "I" (subjective, situational) takes the expression of "modesty" in communicative behavior to a completely different level in intermediate discourse. It can be viewed as if the addressant calls for mutual solution of the problem and appeals for closer, person-oriented communication. In this context the reference to "I" appears to be more suitable than the one given by a counter communicant (social service) in a covert and indirect way. Assumingly, they are interpreted by the client as subjective, lacking argumentation, hiding objective expressions [10]. We would like to emphasize the idea that "I", which is commonly interpreted as an indicator of subjectivity, is not only more suitable at intentional-moral level in this type of discourse, but more accurate as it is more objective by nature. Actually, the author's "We", which is used in such utterances to denote a cooperative action with a third (indirect) counter communicant, and the fact that a concept-value system is shared, can be interpreted by the recipient as the inclusive "We" (i.e. an attempt to make him / her a part of the system), which is a means of manipulation. It appears to be challenging to interpret inclusive "We" as "what I think is similar to what You think / We think". Whereas objectivized "I" makes the addressant exclusively responsible for his / her utterance "it is me who suggests, claims, is sure that..." [10].

Currently there are numerous facts, which prove that there are unstable discourse practices on expression of the degree of access to management of intermediate type of social work discourse. These variable practices can be combined with actions, norms and opinions, which have a potential for institutionalization of resistance at different scales. With a certain degree of credibility, neoinstitutional discourse analysis allows one to describe the points of stability and variability of communicative actions at different levels, which feature the actualization of present institutional rules and the creation, dissemination and implementation of the new ones. It also provides an opportunity to make a complete list of nondiscourse accompanying phenomena in the intermediate domain of communication. The analysis requires to determine the opportunities to apply new institutional theories in discourse practice analysis, e.g. neoinstitutional approaches in sociology, which are oriented at the study of a wide range of organization subjects, rules and management tools, carriers and the stability / variability criteria as regards the processes connected with institutional volatility within the processes, in which social practice is not a given fact. At the same time, a comprehensive study reveals a diversity of relations between heterogeneous empirically proved phenomena (text, discourse practice, social practice). The use of hermeneutic-noematic method allows defining as a primary aspect the means, which provide dominance in this or that sphere of communication, particularly as regards domination or marginalization of certain communication subjects connected with prospective of communication event micro-generation.

\section{Conclusion}

Social discourse functions as claimed in domestic and foreign practice, as a rule, are actualized within the framework of a "bilateral asymmetric" model. The fact can be determined by peculiarities of individual-personal relations and the use of manipulative and commissive aspects in institutional communication practices. The peer-review "arbitral referee" role (social service) can be traced only at the formal level, which results in systematic introduction of assertive models. Taking into account the peculiarities of social interaction between counter communicants and the features of communication contexts, all levels under consideration can characterize social work discourse as an integral part of an institutional type and reveal functional-communicative features of this kind of intermediate discourse

Dynamics of functional-communicative parameters of social work discourse demonstrates comprehensive development of levels of communicative action and the dynamics of interaction between a counter communicant: "manipulation", "reflexive game", "consolidation" and "intentional-moral communication".

The main features of intermediate discourse are preconditioned by extralinguistic goals of communicants. As a result, discourse-genre classification criteria of the given type of discourse do not coincide with the ones of "pure" type discourse as regards the complexity and the extent to which they are represented in written and oral communication.

It should be noted that the general illocutionary intensity of the utterance in socially relevant communication is determined by contextual peculiarities of assertive, manipulative, directive and even commissive nature. On the other hand, the intensity of influence is defined by a pragmatic focus on institutional characteristics (the wish of an addressant to influence a social worker, social service, or feedback influence on the client).

Specification of hierarchical levels of communication action in social work discourse within the framework of analysis of linguopragmatic aspects of institutional characteristics allows one to significantly enhance the methodology of studying different types of institutional discourse with the reference to a particular 
communication context. It can foster the study of an intermediate phenomenon in socially relevant communication, i.e. social work discourse, which is defined as a contaminated type combining social-ritual kind of institutional type and existential kind of personoriented type. Consequently, it can serve to expand the borders of institutional discourse.

The outcomes of the study reveal prospective for further specification of genres representing the institutional discourse. They prove the possibility to apply the methodology of specifying the levels of communication action in different types of discourse. The study of discursive, pragmacentric aspects along with theory of argumentation and philological hermeneutics in pragmadialectic aspect, and functional-communicative criteria of axiology in the process of communication interaction seem to be of special interest.

\section{References}

1. Y.I. Bredikhina, Phil. Sc. 9-2, 88-90 (2017)
2. M.A.K. Halliday, R. Hasan, Language, Context, and Text: Aspects of Language in a Social-Semiotic Perspective (Oxford, University Press, 1989)

3. V.I. Karasik, On Types of Discourse. Linguistic Persona: Institutional and Personal Discourse (Volgograd, Peremena, 2000)

4. L.S. Beilinson, ISLU Philol. Rev. 3, 142-147 (2009)

5. T.A. Shiryaeva, Pyatigorsk St. Ling. Univ. Bulletin 3, 44-49 (2008)

6. T.A. Van Dijk, Disc. \& Soc. 17, 359-383 (2006)

7. Th. Burghard, Aktionsforschung - Wo liegt ihre theoretische Bedeutung für die Veränderung sozialer Praxis, Theorie und Forschung in der Sozialen Arbeit. Gefälligkeitsübersetzung, 91-118 (Neuwied, Luchterhand, 1998)

8. V.I. Karasik, Language of Social Status (Moscow, Gnozis, 2002)

9. K. Stenson, Econ. \& Soc. 22, 42-76 (1993)

10. M. Fenclova, H. Horova, XLinguae Jour., 10, 42-48 (2017) 